\title{
THE INTERDISCIPLINARITY OF MILITARY STUDIES: A SOCIOLOGICAL PERSPECTIVE AND SOUTH AFRICAN APPLICATION
}

\author{
Inaugural lecture - Prof Rialize Ferreira, Dept of Sociology, UNISA
}

\section{INTRODUCTION}

The social sciences developed from social philosophy into independent academic, scientific disciplines in the nineteenth and twentieth centuries, based on ideological and humanistic concerns of the time. Although the military received scant attention its institutional importance was acknowledged. Herbert Spencer (in Segal 2007:46) regarded social organizations as evolving from primitive military forms to advanced industrial societies, while Karl Marx saw military forces as necessary agents to sustain imperialism and industrial capitalism. Max Weber (1968), acknowledged the military as the ideal-type bureaucracy and agent of the state to exercise legitimate organized violence and Emile Durkheim (1951) was concerned with the social impact of the military on suicide. Contributions were also made by Sorokin (1937) and Lasswell (1941) who developed a model of "the garrison state" (Segal 2007:50). Later classics describing the structural relationship between military forces and society include The Soldier and the State by Huntington (1957), The Power Elite by C Wright Mills (1956) and The Professional Soldier by Janowitz (1960), who also in a later work in 1964 focused on the role of the military in development processes in colonized countries (Segal 2007: 50).

While the modern social scientific study of militaries can usually be based on these earlier works, The American Soldier by Samuel Stouffer researched during 1942-1945, was one of the most important contributions on the social significance of the military. The findings were published post-WWII in 1949 and are known as the foundation of military sociology (Caforio 2007:1). This was a joint study by sociologists, psychologists, anthropologists, statisticians and others, and thus a truly interdisciplinary contribution to the study of the military.

According to Bernard Boëne (2008:1) a distinctive characteristic of military studies is the interdisciplinary and internationally integrated nature of the field. "The reason is that except for the 
United States, the numbers of social scientists specializing in military issues in each country are too small to permit peer dialogue and evaluation on a viable scale" (Boëne 2008:1). Therefore International associations such as the European Research Group on Military and Society (ERGOMAS), the Research Committee 01 (RC01) on Armed Forces and Conflict resolution of the International Sociological Association (ISA), as well as the American Inter-University Seminars on Armed Forces and Society (IUS) testify to this and play a crucial role in peer dialogue and evaluation. The associations actively encourage interdisciplinary, cross-national studies. Comparative international research has grown since the end of the Cold War with the shift in mission focus of most militaries towards "operations other than war", focusing on humanitarian peacekeeping missions and peace-building in war-torn countries.

This brief overview of contributions to the field of military studies does not pretend to be exhaustive or inclusive.

\section{INTERDISCIPLINARITY}

The end of the Cold War had a marked effect on national and international armed forces in terms of their organization, structure and function. New research and terms crept into the discourse on the military, such as "fourth-generation warfare", "post-modernism", "asymmetric warfare", and "operations other than war" (Caforio 2007:2). The complexity of recent wars necessitated an interdisciplinary approach to provide greater knowledge and understanding of the changing security context. It is for this reason that sociologists could combine efforts with social psychologists, political scientists and scholars of public administration and development, and even anthropologists to enhance knowledge of problem based research. As Kümmel (2006:3) contends: The reason for "interdisciplinarity lies in the simple truth that the military is a highly complex social phenomenon in itself and one that cuts through various levels, touches several different contexts, and is thus subject to multiple processes of interpretation".

Such interdisciplinarity has enabled military research to integrate concepts, methods, data or epistemology around particular questions, themes, problems and ideas (Caforio 2007:17). This, in fact is imperative to understand military issues given that the issues investigated cut across 
different fields of enquiry of social change, military elites, leadership, socialization, small groups, women and minorities, civil-military relations, the family, race relations and political economy. A shortcoming of interdisciplinary studies with this broad span of enquiry, is that unless there is a unified body of theory articulating research data, risks exist of producing invalid and unreliable findings, resulting from a lack of conceptualization and related hypotheses, thus undermining its scientific worth (Boëne 2008:3). Therefore, a proper theoretical foundation in military studies is needed.

As regards sociology, the strength of the discipline is rooted in the fact that the military institution can be analyzed sociologically by applying existing sociological theory to explain military issues. Berger (1993:42) for example says that: "Sociology is not so much a field as a perspective" .... Thus one can study the military system from perspectives that are quite different, one of which is sociology". The main focus of this lecture is to apply sociological theoretical concepts to explain military issues in the South African National Defence Force (SANDF) after the Cold War era.

\section{SOCIOLOGICAL PERSPECTIVES}

Military sociology employs sociological concepts, theories and methodology to analyze the internal structure, practices and perceptions of armed forces as primary social institutions. The goal is to concentrate on that which is relatively unique to the military institution, rather than what it has in common with other institutions or large organizations (Siebold 2001:3).

Some of the topics generally covered in military sociology include processes related to human resource issues, manpower models relating to the transition from conscription to all-volunteer forces, military unionism, leadership, policy issues, veterans, historical cases, women in the military, international affairs, the military as participants in humanitarian peace missions, civilmilitary relations and civil control of the military. Military members provide an abundant source of information to address a broad range of sociological specializations including demography, stratification, social psychology and families. 
Military issues require theoretical clarification to conduct empirical research. However, after reading several texts regarding military institutional issues, I found that sociological "grand theories" are seldom used in analyses. Only strands of functionalism and conflict theory, applied by means of middle-range theories and different theoretical models, are used by most military sociologists. References are made to systems theory or functionalism because of the military's position as a societal system. It is studied in terms of a system of roles based on values and norms, structures, functions, patterned behavior and adaptation to change. Conflict theories relate to issues in post-colonial countries and "greed and grievance models" of analyses are mostly employed. Organizational models refer to the bureaucratic organization of the military. Therefore, the military can be explained within different sociological theories, such as functionalism, conflict and organizational theories.

However, when selecting a suitable theoretical viewpoint for research, the functionalist perspective holds certain advantages because it indicates causal relationships in the military system which excludes the problem of single factor causation. Another advantage is that the military institution has to adapt to an ever changing society and by doing so the influence of different system adaptations can be identified in the different role actors. "Changes in military organizations reflect, and sometimes affect, large-scale social changes in the broader society" (Moskos 2000:14). One of the first attempts of theorizing these changes during 1994 was by Charles Moskos. In his book on the "Post-Modern Military", Moskos (2000:15) tried to capture the nature of military institutional change by placing this into three historical time periods, namely "Early Modern" (1900-1945), “Late Modern" (1945-1990) and "Post-modern" (1990post-Cold War) periods (Nuciari 2007:82). This model was an ideal-typical development construct of transformation and civil-military relations in the United States (US) (Moskos 2000:14-15). Different variables were listed in this model to explain underlying causes of change from a historical viewpoint. These can be applied to armed forces in a comparative context, thus, also to the SANDF. Therefore, in this lecture this theoretical framework will be applied to relevant military issues and changes in the SANDF and explained accordingly. 
A table of trends of Moskos's (2000:15) paradigm of Force variables, Modern, Late Modern and Post-modern eras is applied to explain military issues. The Modern military emerged in the $20^{\text {th }}$ century and was associated with the nation-state, conscripted mass army, war-oriented in mission, masculine in composition and ethos and different from structure and culture of civilian society. The Late Modern era is, however, deemed irrelevant as it was not applicable to South Africa (SA) since the military developed from the Modern era straight into the Post-modern era due to societal and political transformation affecting the SANDF's structure and roles (Cilliers \& Heinecken 2000:242-264). The Post-Modern SANDF has become multipurpose in missions, fully integrates women in a smaller volunteer professional force under civil control, becoming more like a civilian organization.

\begin{tabular}{|l|l|l|l|}
\hline Force Variables & $\begin{array}{l}\text { Modern (pre-Cold } \\
\text { War) 1900-1945 }\end{array}$ & $\begin{array}{l}\text { Late-Modern (Cold } \\
\text { War) 1945-1990 }\end{array}$ & $\begin{array}{l}\text { Post-modern (post-Cold } \\
\text { War) since 1990 }\end{array}$ \\
\hline Perceived threat & Enemy invasion & Nuclear War & $\begin{array}{l}\text { Sub-national; ethnic violence } \\
\text { and terrorism }\end{array}$ \\
\hline Force structure & $\begin{array}{l}\text { Mass army, con- } \\
\text { scription }\end{array}$ & $\begin{array}{l}\text { Large professional } \\
\text { army }\end{array}$ & Small professional army \\
\hline $\begin{array}{l}\text { Major mission defini- } \\
\text { tion }\end{array}$ & $\begin{array}{l}\text { Defence of home- } \\
\text { land }\end{array}$ & Support of alliance & $\begin{array}{l}\text { New missions: peace- } \\
\text { keeping, humanitarian }\end{array}$ \\
\hline $\begin{array}{l}\text { Dominant military pro- } \\
\text { fessional }\end{array}$ & Combat leader & Manager or technician & $\begin{array}{l}\text { Soldier-statesman; soldier- } \\
\text { scholar }\end{array}$ \\
\hline $\begin{array}{l}\text { Public attitude towards } \\
\text { military }\end{array}$ & Supportive & Ambivalent & Indifferent \\
\hline Media relations & Incorporated & Manipulated & Courted \\
\hline Civilian employees & Minor component & Medium component & Major component \\
\hline $\begin{array}{l}\text { Women's role } \\
\text { In a separate corps }\end{array}$ & Partial integration & Full integration \\
\hline Spouse and military & Integraded part & Partial involvement & Removed \\
\hline Homosexuals & Punished & Discharged & Accepted \\
\hline $\begin{array}{l}\text { Conscientious } \\
\text { objection }\end{array}$ & Limited or prohibited & Routinely permitted & $\begin{array}{l}\text { Subsumed under } \\
\text { service }\end{array}$ \\
\hline
\end{tabular}

Moskos (2000:15).

\section{THEORETICAL APPLICATIONS TO SOUTH AFRICA}

Since the ideal-typical developmental construct "Post-modern" military refers specifically to the explanation of transitions in militaries and civil-military relations under way in the post-Cold war period, it is a useful, acknowledged military sociological construct, "explaining what has happened in the past and predicts what is likely to happen in civil-military relations in this 
period" after the Cold War (Moskos 2000:14). Therefore, it is considered a suitable theoretical model to explain South African military changes since 1990.

The meaning of the term 'Post-modern' is, however, debatable since it has many different meanings for different people. It is not the aim to render a full explanation of Post-modernism, since it is sufficient to note that "Post-modernism subverts absolute values and introduces a profound relativism into discourse" (Moskos 2000:4). In this theoretical model the terminology is linked to a specific historical period of transformation in militaries and civil-military relations after 1990.

The fast transition in the SANDF into the "Post-modern" era and bypassing of the "Late Modern" era was caused by radical political transformation (Cilliers \& Heinecken 2000:42). This peculiar development was ascribed to the fact that SA was internationally isolated from the late 1960s to 1990 until the unbanning of the ANC. Compulsory conscription was abolished in 1994 and the mission of the military changed drastically in a no-threat scenario. A new force design with new roles and functions were required.

For the purpose of this lecture only trends of the Post-Cold War era, highlighting important areas of change in the relationship between the SANDF and SA society are applied. These refer to civil-military relations and civil control, the institutionalization of human security and peacekeeping missions where asymmetric warfare is practised. These trends implicitly refer to trends in the theoretical model describing ethnic violence in intrastate wars and small professional voluntary armies linked to policy, structural and role changes in the SANDF.

\section{Civil-military relations.}

Fundamental reforms took place in military structure, function, organisation and civil-military relations, which refer to the interactions between armed forces as institutions and the society they belong to. In line with the characteristics of the Moskos (2000:14) paradigm of changing trends in civil-military relations in Post-modern militaries, the SANDF was democratized during the early 1990s and its civil-military relations changed from an autocratic top-down structure to 
a participatory system with civilian input, or civil control. The integration of eight different armed forces into one national defence force caused new patterns of civil-military relations and military culture to develop (Williams 1998:28). Civil control and parliamentary oversight of the military by democratically elected civilians in Parliament, as representatives of the state became compulsory and a civilian Defence Secretariat was instituted in 1995. In 1996, within a relative short period of time, the democratically elected government managed to establish mechanisms, legislation and processes to ensure appropriate civil control of the newly integrated SANDF by means of a new Constitution, the White Paper on Defence and the broadly consultative Defence Review in 1998.

By civil control is meant the obedience and loyalty which the military, as an instrument of the state owes to civis, the state, to uphold order by advising on the formulation of defence policy and by helping to implement it (Chuter 2000:25). The SANDF influences the formulation of many government policies, eg. foreign policy options which would otherwise not exist. The challenge is to ensure that the military participates in defence policy-making without undermining or usurping the authority of civilian decision-makers to whom the military has this civic duty, like the civilian Minister and the President. Civilians are entitled to dictate military security policy, while military elites are free to determine what military operations are required to implement policies.

Civil-military relations thus refer to the division of powers within society amongst the political elite, the military elite and civilian society itself (Williams 1998:28). This arrangement is called the "balanced model" and depends on the balance of power, which could change when power relations shift and different formal relations prevail. Civil supremacy over the military is thus a political principle of democracy as well as an expression of military professionalism (Liebenberg 2001:96). However, after a few years the conclusion was made that the "balanced model" was not a flawless one. It has many uncertainties and contentious issues to deal with, like the much debated procurement of armaments in the Strategic Defence Package by the civilian Defence Secretariat. 


\section{The institutionalization of Human security}

According to Moskos (2000:27) the Post-modern military "ultimately derives from the decline in the level of threat to the nation, the rise in identity politics based on ethnicity, gender and sexual orientations, the acceptance of fundamental human rights in accordance with civilian value systems for the military". Given the no-threat scenario of war in SA, a shift occurred from a focus on purely military security towards a human-centered security policy. Topics related to human security were researched, like identity, gender, racial integration, military unionism and the concept of new security thinking.

The UN Development Program's 1994 Human Development Report portrayed human security as a people-centered approach (rather than state-centered), describing the most basic components as "freedom from fear and freedom from want," and asserting that it should offer safety from chronic threats like hunger, disease and political repression (Ferreira \& Henk 2005: 2-3). This all-encompassing, holistic approach to security of citizens was propagated for most governmental institutions. The intention is here to explain how the concept of human security is applied to the military to coincide with post-modern civil-military trends.

As the SA society became democratic, so the nature of the SANDF changed too and consequently the national conception of security was redefined. The new South African Constitution (1996), the White Paper on Defence (1996), the Defence Review (1998) and the White Papers on Intelligence (1995) and on Participation in International Peace Missions (1999) were infused with human security principles, with major focus on human security in conjunction with state security and came to include not only military, but political, economic, social, technological and environmental dimensions. This broadened the field from military studies to human security, including aspects affecting the quality of life of people, freedom, justice, prosperity and development for all South Africans.

This new approach to security had interesting implications for the roles and missions of armed forces as it raised questions about the relevance of the military, police and intelligence agencies as the sole actors responsible for security. Priorities started to shift away from defence to 
development, resulting in massive defence budget cuts, rationalization of personnel resulting in a smaller, volunteer professional defence force, including all races and gender, and the reprioritization of defence roles and functions. Hence, South Africa has consciously applied human security principles to society and its armed forces and this experience thus offers potentially useful insights into the "art of the possible" in adapting governmental institutions to human security ends (Ferreira \& Henk 2005:3). This fact is evident in two key aspects; in South Africa's support for Africa's security situation and an increasing willingness to participate in external peace operations (Ferreira 2007:242).

\section{Humanitarian Peacekeeping missions in Africa}

In Africa, most of the present conflicts are unconventional, asymmetric small wars which have erupted since colonial independence in the 1960s. African intrastate wars are different from "old wars" in the sense that they usually imply fighting "against every single member of the other ethnic, religious or otherwise defined group" (Von Bredow 2007:167). Forced migration, ethnic cleansing and genocide, as well as religious intolerance are aspects of these wars, which Kaldor (1999) classifies as "new wars" in terms of violence and financing. Financial resources usually originate from illegal sources, like drug trafficking, smuggling, kidnapping and prostitution which are all leading to social problems in the relevant societies.

To gain control and remain in power, political leaders became increasingly autocratic, corrupt and dictatorial and opposition parties were often suppressed through extreme violence and even genocide. Not surprisingly, this non-compliance with democratic principles coupled with poor governance and extreme poverty gave rise to rebel movements. The endless cycles of war in Africa has hampered development initiatives and caused untold misery for millions of innocent civilians caught up in these conflicts. However, attempts to put an end to the violence are fraught with difficulties not only because the political objectives of the various fighting factions are often unclear, but because so many different actors are involved. When ceasefire or peace agreements are eventually reached, these are often violated by one or more of the parties as "peace" may not be to their advantage. Gaining control over comparatively strong 
rebel forces, who are able to operate in hostile terrain using increasingly sophisticated weapons to gain control of strategic resources and achieve various political, economic and ideological objectives, become exceedingly difficult for conventional forces who are often not trained or equipped for such asymmetric interventions.

In the Post-Cold War era a new wave of intra-state wars emerged, based on poor governance of weak states and social concerns. Motivated by revenge, lust for power, ethnicity, religion, ideology or other unifying bonds, various belligerent groups started to oppose incumbent governments (Corbin 2001:2), by using lethal light weapons and guerrilla tactics. Given the unconventional and indirect strategies adopted by these non-state actors, this type of warfare came to be termed "irregular" or asymmetric warfare.

There are many definitions of asymmetric warfare. Grange (2000:1) defines this "as conflict deviating from the norm, or an indirect approach to a counterbalance of force" using "their own strength against the other's weakness". Here belligerent groups are not opposing "military superior powers", but ill-equipped and relatively small and poorly trained national armed forces (Ferreira 2010:49). Typically they use terrorist or guerrilla tactics such as hit and run to deal stunning blows on their opponents. This type of warfare also favours indirect approaches to counteract the opponents' influence, such as using or coercing the civilian population to assist them in their fight against opponents. The tactics used extend beyond the use of militarised means (Grange 2000:4). Typically asymmetric warfare is waged through social, political and economic strategies, as well as through psychological warfare - winning the hearts and minds of the population through information, disinformation and manipulation (Botha 2007:4). Thus, within the African context asymmetric warfare combines guerrilla tactics with civil disobedience, social, cultural and economic strategies, as well as disinformation to attack the opponent and to maximise their political influence (Jackson 2007:4).

SA as regional economic and military power has come to play a leading role as the continent's peace maker and is a relative newcomer to peace operations. She only became involved in earnest after the promulgation of the White Paper on South African Participation in Peace 
Missions in 1999. A shift in defence policy accommodated a broader, more inclusive mandate and roles for humanitarian peacekeeping missions, but SA would only participate when it had national interests for doing so and to avoid the spill-over effects of African conflicts that might cause a real threat and long-term instability in the region. Personnel have served in United Nations and African Union missions in Burundi, Ivory Coast, Ethiopia, Democratic Republic of Congo (DRC), Central African Republic, Sudan, Comoros and Liberia among others. The major deployments have been to Burundi (terminated 30 June 2009), with current operations in the DRC and Darfur, Sudan. In the past eleven years the SANDF has taken part in 14 peace missions and is now the largest troop-contributing country to $U N$ and $A U$ missions on the continent, with almost 3000 members deployed on various missions (DefenceWeb 2010). This has placed heavy demands on the SANDF and its personnel, in terms of transport and logistical support. The recent Strategic Defence Package did not alleviate the situation, since the focus of these purchases was mainly on the Navy and the Air Force, but not on the Army as such. Orders for Boeing Transport aircraft for peacekeepers were cancelled during 2010. Although there have been numerous requests for SA to intervene in Somalia, this has been avoided due to problems of operational overstretch and the absence of peace agreement. However, a naval vessel has been dispatched to the Mozambique Channel, which has been the site of recent attacks by Somali pirates, but not as part of any international mission (African Press Agency, 2011).

SA peacekeeping deployments on foreign missions are voluntary although there is an obligation to serve if nominated. A wide range of personnel are deployed depending on the nature of the mission and the ratio of males to females has been as high as 70/30 in some cases. Personnel are deployed on six months rotation basis and are paid in the form of allowances depending on the type of accommodation, classification of the mission (dangerous or not) and on the standard UN/AU allowances per month.

These deployments have not been easy, partly due to the restrictive nature of the different mandates for peacekeeping in the DRC and peace enforcement in Sudan, but mostly because personnel have lacked the necessary logistical support, equipment, knowledge and training to deal with these complex conflicts. Often it is not clear whether the motives for conflict are 
indeed grievances, or whether it is greed. According to Botha (2007:4-5) conflicts rooted in grievances relate to issues of inequality, political expression, control over territories and natural resources, closed political systems and religious and ethnic motivations for conflict, as well as unemployment and poverty. However, Collier and Hoeffler (2002:1) claim that most of the conflicts in Africa, especially where countries have an abundance of globally traded commodities such as diamonds, oil and timber are because of greed, rather than grievance. Given the poor infrastructure, difficult terrain, lack of control of territory and permeable borders of many African states, countering the activities of rebel forces is a major challenge, especially child soldiers, who are extremely resilient and quick to point guns at peacekeepers.

Currently research is conducted on the typical challenges associated with such operations from the first time peacekeepers arrive on the mission to the difficulties they experience with the rules of engagement, experiences whilst deployed, the challenges they face interacting with different role players, to the personal satisfaction and psychological stresses these asymmetric operations pose (Ferreira \& Heinecken 2011). This research has confirmed that Africa's weak states have neither the capacity nor capability to counter the rebel forces that use unconventional, asymmetric tactics and non-military means to gain political and economic control.

In Africa peacekeepers do not have the relatively straightforward task of merely policing agreements between opposing parties in intrastate wars. Cross-border actions do take place (e.g. Rwanda and the DRC) because countries are simply incapable of controlling their borders since neighbouring countries have involved themselves in the internal affairs of others and allowed their territory to be used by rebel groups. Peacekeepers are plunged into intractable problems and called upon to recreate collapsing states, intervene in vicious civil wars and enforce, if needed, peace settlements (e.g. in Burundi and Sudan) between conflicting ethnic and religious parties whose commitment to peace is mostly uncertain (Cilliers 1999:139).

Peacekeeping operations include non-military functions like mediation, civilian protection and conflict resolution in countries whose national interests and security are at stake. This concept 
is called "Operations Other Than War" and is usually employed to avert threats to peace between and within nations. These operations put a huge burden on the capabilities and resources of not only the United Nations, but also those of participating, troop-contributing countries. Although participation in peacekeeping is commendable, it is by nature a costly business. The extent of peacekeeping in Africa is not limited only by political will, but by the availability of funds as well. South Africa experiences a position where funds for peacekeeping have to come from the existing primary role budget, while no extra funds are made available for secondary roles. "Lean peacekeeping" will require peacekeepers to "make do" with available resources (Cilliers \& Mills 1999:4). The reality is that African peacekeeping will remain underfunded for time to come.

Although operations are expected to ensure positive outcomes such as promoting stability and durable peace to rebuild and develop host populations to uphold democracy and human rights, peace operations may fail to deliver intended good results (Aoi et al 2007:4). Unintended negative incidents are caused by a few "bad apples" who, for example, act outside the norm by committing atrocities such as rape and sexual abuses, which are regarded as part of the nonlinear and dynamic behaviour of complex systems and a systemic consequence of peace operations (Aoi et al 2007:5). However, peacekeepers are still expected to abide by the rules of engagement and customs of the host society.

The long-term effects of these conflagrations would hamper social, economic and political development and reform. While it is important to recognize the notion "African solutions for African problems", it is also crucial for Africans to assume greater responsibility and willingness to resolve conflicts and to keep fragile peace agreements (Landsberg 1999: 47). The contention is to prevent side-effects and if there is no peace to keep like in Somalia, peacekeepers should not be there at all.

\section{CONCLUSION}

The Moskos (2000:14) ideal-typical development construct, or theoretical model, displaying trends in the Post-modern period of transformation in military institutions has been applied 
successfully to the SANDF to explain the military's relationship to society by referring to new civil-military relations and the institutionalization of human security, leading to humanitarian peacekeeping. With the help of sociological concepts, the South African military was analyzed by referring to historical events that have shaped the present, eg. threat perceptions shaping military forces and missions (Williams 2000:265). Political changes generated new challenges for society and it had to respond by adapting its structures and skills to meet new requirements, such as adapting governmental institutions to human security ends. The SANDF has rearranged its military structures and approaches to conform to civil-military trends and to participate in humanitarian peace missions. Not only did the structure and purpose of the military change, but so did the values to become more aligned with civilian values and developing trends in society.

\section{REFERENCES}

African Press Agency. 2011. South African Navy to Patrol Mozambique Channel Against Piracy, http://www.netnewspublisher.com/south-african-navy-to-patrol-mozambique-channel, 4 February 2011, accessed 2011/03/21.

Aoi, C., De Coning, C. \& Thaku, R. 2007. Unintended consequences of peacekeeping. Centre for International Political studies. Electronic briefing paper. No 56/2007. University of Pretoria. URL: www.up.ac/academic/cips

Berger, P.L. 1993. Sociology: a disinvitation? Dialogue, 102(4). pp. 38-42.

Boëne, B. 2008. Revue of G Caforio(ed). Social Science and the Military: an interdisciplinary overview. The Journal of Power institutions in post-Soviet Societies [online], Issue 8/2008. URL: http://pipss.revues.org/index1303/html

Botha, A. 2007. Relationship between Africa and International Terrorism: Causes and Linkages. Paper presented at the Conference on Southern African and International Terrorism. Brenthurst Foundation, Tswalu, 25-27 January 2007.

Caforio, G. (ed.) 2006. Handbook of the Sociology of the military. London: Kluwer Academic.

Caforio, G. 2007. (ed.) Social sciences and the military: and interdisciplinary overview. London: Routledge.

Chuter, D. 2000. Defence Transformation: a short guide to the issues. ISS Monograph series no 49. August. Brooklyn Square: Institute for Security Studies. 
Cilliers, J. 1999. Regional African peacekeeping capacity - mythical construct or essential tool? In Cilliers, J. \& Mills, G. 1999 (ed). From peacekeeping to managing complex emergencies: peace support missions in Africa. ISS: Natal Witness: 133-152.

Cilliers, J. and L. Heinecken. 2000. South Africa emerging from a time-warp. In The Post-modern military. Moskos, CC., J.A.Williams and D.R. Segal. eds. New York: Oxford University Press: 242-264.

Cilliers, J. and G. Mills. 1999. From peacekeeping to managing complex emergencies: peace support missions in Africa. Institute for Security Studies and SA Institute for International Affairs: Natal Witness. pp. 1-7.

Collier, P. \& Hoeffler, A. 2002. Greed and Grievance in Civil War. World Bank publication. CSAE WPS/2002-01. March 2002.

Corbin, M. 2001. Reshaping the military for asymmetric warfare. [Online]. Terrorism project, October. Centre for Defense Information. Available at http://www.cdi.org/terrorism/asymmetric.cfm (Accessed 16.10.09)

DefenceWeb. 2010. 14 SA peace missions in 11 years, 27 August 2010. Http://www.defenceweb.co.za Accessed 2011/07/12.

Ferreira, R. 2005. Civil Control over African Militaries. Africanus Vol 35 (1) 2005 Africanus Vol 35 (1) 2005

Ferreira, R. 2007. Civil-military relations and human security in South Africa. Politeia, Vol 26(3). pp. 229251.

Ferreira, R. \& Henk, D. 2008. Operationalizing Human security in South Africa. American Armed Forces and Society. Published 3 April 2008 by Sage publications.

Ferreira, R. 2009. Consequences of humanitarian peacekeeping in Africa. Scientia Militaria. Vol 37(2), pp. 25-42.

Ferreira, R. 2010. Asymmetric warfare in African conflicts. Scientia Militaria. Vol 38(1). pp. 45-67.

Ferreira, R and Heinecken, L. 2011. Asymmetric Warfare and African Peace Missions: The experience of South African Military personnel. Paper delivered at the ERGOMAS conference in Amsterdam June 2011.

Grange, D.L. 2000. Asymmetric warfare: Old method, new concern. National Strategy Forum Review. Winter 2000:1-5.

United Nations Development Program, 1994. Human Development Report. Available at: http://www.undp.org/hdro/94.htm (accessed 2006-09-13).

Huntington, S.P. 1957. The soldier and the state: the theory and politics of civil-military relations. Cambridge, Mass.: Belnap Press of Harvard University Press.

Jackson, P. 2007. Are Africa's Wars part of a Fourth Generation of Warfare? Contemporary Security Policy. 28(2): 267-285.

Kaldor, M. 1999. New and old wars: Organised Violence in a global era. Cambridge: Polity Press. 
Kummel, G. 2006. Handbook of the Sociology of the military. In Caforio, G. (ed.) 2003. London: Kluwer Academic.

Landsberg, C. 1999. Willing but unable: Small states and peacekeeping in Africa. in Cilliers, J. and G. Mills (eds). From peacekeeping to managing complex emergencies: peace support missions in Africa. ISS: Natal Witness. pp. 45-54.

Liebenberg, J. C. 2001. Civil control over security institutions in South Africa: Notes on replicating the experience in Africa. Southern Africa on the threshold of the third millennium. Moscow: Russian Academy of Sciences Institute for African studies. pp. 83-97.

Moskos, C.C. 2000. Towards a Postmodern Military: the United States as a Paradigm. In The Postmodern Military: Armed Forces after the Cold War. In Moskos, C.C., Williams, J.A. and Segal, D.R. (eds). New York: Oxford University Press. pp. 14-31.

Moskos, C.C., Williams, J.A. and Segal, D.R. (eds) 2000. The Post-modern Military: Armed Forces After the Cold War. New York: Oxford University Press.

Nuciari, M. 2003. Models and explanations for military organization: an updated reconsideration. In Caforio, G. Handbook of the Sociology of the Military. London: Kluwer Academic. pp. 61-85.

Siebold, G.L. 2001. Core issues and theory in military sociology. Journal of Political and Military Sociology. Summer 2001.

South African Department of Defence. 1996. South African White Paper on Defence. Pretoria: Department of Defence.

South African Department of Defence. 1998. South African Defence Review. Pretoria: Department of Defence.

South African Department of Foreign Affairs. 1999. White paper for participation in International Peace Missions. Pretoria: Foreign Affairs.

South African Department of Intelligence. 1995. South African White Paper on Intelligence. Pretoria: SA Government.

Segal, D.R. 2007. Current developments and trends in social research on the military. In Caforio, G. 2007. (ed.) Social sciences and the military: and interdisciplinary overview. London: Routledge. pp. 46-66.

Von Bredow. W. 2007. Conceptual insecurity: new wars, MOOTW, CRO, terrorism and the military. In Caforio, G. 2007. (ed.) Social sciences and the military: and interdisciplinary overview. London: Routledge. Pp. 163-180.

Williams, J.A. 2000. The Postmodern Military Rconsidered. In Moskos, C.C., Williams, J.A. and Segal, D.R. (eds) The Postmodern Military: Armed Forces after the Cold War.. New York: Oxford University Press. pp. 265-277.

Williams, R. 1998. Towards the creation of an African civil-military relations tradition. African Journal of Political science. Vol. 3(1) p.20-41. 